\title{
Fatal fashions and caring actions: Florence Augusta Merriam Bailey and the rise of avian conservation
}

\author{
WIETEKE A. HOLTHUIJZEN \\ Department of Biological Sciences, \\ Northern Illinois University, \\ United States of America
}

\section{Abstract}

Often overlooked, the North American ornithologist Florence Augusta Merriam Bailey (1863-1948) was the author of the first modern bird identification book in 1889, Birds through an Opera Glass. Previously, bird identification and ornithology were luxury hobbies or academic pursuits limited to a small fraction of the American public, namely the affluent upper class or progressive conservationists. Bailey, though, served as a key catalyst in the rising avian conservation sentiment during the early twentieth century in response to the widespread 'feather trade'. Through her writings, Bailey developed an important middle ground that incorporated both scientific arguments for conservation as well as moral and emotional ones, which not only made her oeuvre widely accessible, but also, in a practical way, effectively spread the message of conservation to a much larger audience. To place bird identification in a more meaningful context, Bailey included scientific explanations and ecological insights in her bird guides and encouraged the reader to interact with nature through quiet observation of living birds in their natural habitat. Bailey highlighted key relationships between birds and their surroundings by subtly introducing basic concepts of evolution and natural selection, adaptation, niche partitioning and ecology, even though many of these concepts were not formally known as such at the time. In doing so, Bailey essentially democratised ornithology with the objective of actively engaging ordinary people in the process of conservation.

Keywords: avian conservation, gender and environment, ornithology, bird identification, natural history

\section{Introduction}

Frank Chapman, a pioneering ornithologist of the late nineteenth century, recorded 40 different species of birds as he walked through downtown Manhattan in $1886 .{ }^{1}$ None of the birds he observed moved on their own account; instead, they were all

1 Jennifer Price, Flight Maps: Adventures with Nature in Modern America (New York: Basic Books, 1999), 57-76. 
dead, stuffed and mounted upon the hats of wealthy, upper-class women following the newest fashion craze. Decorative applications had begun humbly with a few feathers, but soon became increasingly extravagant and incorporated extensive arrangements of plumes, wings, entire birds, and even fruit, flowers, fur, mice and small reptiles. Long, elegant, white plumes were especially sought after; between 1897 and 1911, more than 1 million heron and egret skins alone were sold to the millinery market. ${ }^{2}$ As a result, hunters and 'plumers' killed more than 15 million American birds, ranging from small hummingbirds to large waterfowl, each year to meet the booming demands of the latest fashion trend. ${ }^{3}$

The widespread massacre of birds for this market elicited strong opposition and gave rise to two distinct approaches to avian conservation. One group of conservationists, among them Theodore Roosevelt, fervently believed that all birds should be 'protected in every way. ${ }^{4}$ Beginning in 1903 with Pelican Island-the last breeding colony of brown pelicans on the east coast of Florida and one of the sites hardest hit by feather trade hunters and 'plumer' gangs-Roosevelt began to protect birds by safeguarding their habitat through a series of federally protected bird reservations, thereby physically separating birds from people on the basis of biological conservation. ${ }^{5}$ While his efforts were successful in the sense that he set aside 51 such reservations, only a relatively small group of fellow conservationists, scientists and ardent outdoorspeople shared his approach to bird conservation. ${ }^{6}$ Indeed, Roosevelt's decisions caused strong reactions and these became quite violent at times. In 1905, the actions of a gang of plumers escalated to the murder of an American game warden, Guy Bradley, who was single-handedly responsible for enforcing the ban on bird hunting throughout the Everglades. ${ }^{7}$

A second conservation approach-spearheaded by wealthy, upper-class women, notably Harriet Lawrence Hemenway and Minna B. Hall-resulted in the establishment of the National Association of Audubon Societies throughout the eastern United States in 1896, with the aim of protecting native birds and specifically discouraging the purchase and use 'for ornamental purposes [of] the feathers of any wild birds' ${ }^{8}$ Unlike Roosevelt's federal bird reservations, the Audubon Societies' approach to avian conservation was not a consequence of environmental concern for birds nor even the inherent value of birds as one of 'God's creatures'.

\footnotetext{
2 Joan Boudreau (exhibition curator), 'The feather trade and the American conservation movement', americanhistory.si.edu/feather, accessed 13 July 2020.

3 Kathy S. Mason, 'Out of Fashion: Harriet Hemenway and the Audubon Society, 1896-1905', The Historian 65 (2001): 1-14, doi.org/10.1111/1540-6563.651014.

4 'To protect the birds', New York Times, 24 March 1899.

5 Douglas Brinkley, The Wilderness Warrior: Theodore Roosevelt and the Crusade for America (New York: Harper Perennial, 2009), 492-4.

6 Stewart L. Udall, The Quiet Crisis (New York: Avon Books, 1963), 144-5.

Brinkley, The Wilderness Warrior, 495-9.

Mason, 'Out of fashion', 1-14.

Price, Flight Maps, 90.
} 
Rather, the women who led this movement were motivated by their perceived role as chief proponents and defenders of moral and civilised behaviour in American society. Killing birds for 'vain' reasons to uphold the reputation (via feathered hats) of these upper-class women directly threatened 'higher womanhood'; for a 'dead tern on a hat was ugly, a desecration of nature's beauty and a travesty of womanhood' whereas a live bird truly embodied beauty. ${ }^{10}$ Thus, the Audubon Societies came to avian conservation not necessarily by scientific reasoning but by (re)defining the social roles and conduct of women.

Notably, the Audubon Societies were largely organised and led by women (specifically upper-class women and also visible socialites), who leveraged their social status and economic clout to effect bird conservation via legislation. ${ }^{11}$ Indeed, Hemenway and Hall (as well as many other women from the Audubon Societies) implemented and partook in the boycott of hats and clothing adorned with feathers; ${ }^{12}$ in turn, they are often credited with the passage of the Lacey Act of 1900 as well as the Weeks-McLean Act of 1913 (later replaced by the Migratory Bird Treaty Act of 1918), which specifically prohibited the hunting and marketing of migratory birds, as well as the importation of wild bird feathers for use in clothing and fashion. ${ }^{13}$ However, to categorise this particular avian conservation approach (in comparison to bird protection efforts by Roosevelt and fellow conservationists) as a movement involving only the Audubon Societies and elite women socialites of the upper class ${ }^{14}$ is an oversimplification. Moreover, the bird conservation efforts implemented by these Audubon Societies were often aristocratic in nature; that is to say, the boycott of feathered millinery products was a moral and economic decision available only to a select number of wealthy, privileged women.

However, there is a more nuanced context to the avian conservation movement (mainly) led by women from the late 1800s through to the early 1900s; within this 'Audubon Movement', ${ }^{15}$ some women took a different approach to conservation. They sought to broaden interest in birds, in particular encouraging the public to consider birds as more than plumes on the hat of a wealthy person-they wanted the public to see and know the birds around them. ${ }^{16}$ These women - early ornithologists, naturalists and nature writers-developed a keen interest in birds, not necessarily as a moral calling, but out of curiosity and the desire to share knowledge, thereby spurring a deeper understanding and appreciation by the public and gaining

\footnotetext{
10 Ibid., 78-82.

11 Mason, 'Out of fashion', 1-14.

12 Boudreau, 'The feather trade'.

13 Jessica Scott and Andrea Folds, 'From friend to foe: The complex and evolving relationship of the federal government and the migratory birds it is bound to protect', Environmental Law 49 (2019): 191-4.

14 Boudreau, 'The feather trade'.

15 Ibid.

16 Deborah Strom, ed., Birdwatching with American Women: A Selection of Nature Writings (New York: W. W. Norton \& Company, 1986), ix-xxviii.
} 
broader support for avian conservation. Through their careful observations and writings, these women ornithologists took inspiration from transcendentalismrelated preservation ethics and bound it with scientific inquiry, in a sense, applying and contemporising ornithology. ${ }^{17}$ Instead of developing complex manuals of identification, these women ornithologists created lush, detailed stories about bird life: these women realised birds. The list of these women is long, yet many names have been lost with time, suppressed or simply ignored; to name a few: Neltje Blanchan De Graff Doubleday, Fannie Pearson Hardy Eckstorm, Amelia Rudolph Laskey, Louise de Kiriline Lawrence, Harriet Mann Miller, Margaret Morse Nice, Althea Rosina Sherman, Cordelia Johnson Stanwood, and Mabel Osgood Wright. One such profound observer of birds, key in transforming and democratising ornithology, was Florence Augusta Merriam Bailey (1863-1948).

As a budding young ornithologist at Smith College in 1882, Florence Augusta was appalled by the latest fashion trend common among her female friends and soon became involved in the rising bird conservation sentiment. ${ }^{18}$ However, bird conservation (then) appealed to only a small, elite fraction of the American publiceither the rich, upper class or progressive conservationists. Through her writings, Bailey developed an important middle ground that incorporated both scientific arguments for conservation as well as moral and emotional ones, which not only made her oeuvre widely accessible, but in a practical way quietly spread the message of conservation to a much larger audience. In her books, Bailey described birds in an understandable manner so that everyone-' not only young observers but also laymen'-would be able to appreciate and identify the birds in their backyards and beyond, and as such produced the first 'modern' bird guides. ${ }^{19}$ In addition, by incorporating basic biology and ecological insights as well as encouraging interaction with the environment through quiet observation of living birds in their natural habitat, her books helped establish a better public understanding of birds and their ecological importance. Finally, through her personal anecdotes of experiences with birds, Bailey created an emotional bond between her readers and the birds that she sought to protect, resulting in a new-found morality regarding the massacre of birds for decoration. Ultimately, her contributions helped create an enduring and collective approach to bird conservation.

17 Thomas R. Dunlap, In the Field, among the Feathered: A History of Birders and Their Guides (Oxford: Oxford University Press, 2011), 13-36, doi.org/10.1093/acprof:osobl/9780199734597.003.0002.

18 Harriet Kofalk, No Woman Tenderfoot: Florence Merriam Bailey, Pioneer Naturalist (College Station: Texas A\&M University Press, 1989), 23-39.

19 Florence A. Merriam, Birds through an Opera Glass (Boston, MA: Houghton, Mifflin and Co., 1889), ix. 


\section{Of goatsuckers and chippies}

Prior to Bailey's bird books, only a narrow fraction of society had access to identification manuals, guides and ornithological texts due to the price and nature of the writings. Although detailed and beautiful, John James Audubon's The Birds of America (1827-38) was an enormous eight-volume collection of 425 plates (illustrations) of birds with an equally hefty price tag of $\$ 970$ in 1839 (approximately $\$ 26,742$ adjusted for inflation in 2020) - neither a practical nor economically feasible option for identifying birds, whether in the backyard or the backcountry. ${ }^{20}$ Other famous bird books of this period, such as Alexander Wilson's nine-volume American Ornithology (1808), followed the same trend of extravagant and expensive multi-volume works. It was not until the late nineteenth century that ornithological texts and guides became smaller and more affordable. Yet these early identification guides, such as John B. Grant's Our Common Birds and How to Know Them (1891), were written and organised in a technical manner and relied upon scientific terminology, Linnaean taxonomy and complicated identification keys-all of which required a pre-existing knowledge of ornithology. ${ }^{21}$ Bailey, on the other hand, created the first 'modern' bird guides by borrowing 'only necessary statistics from the ornithologies, giving untechnical descriptions, and illustrating keys based on such colors and markings as any one can note in the field'. ${ }^{22}$

Bailey's first bird books came about perhaps not as the result of a concentrated effort to ameliorate the then current bird identification manuals, but rather to address a specific need. During her time at Smith College, Bailey organised a local Audubon Society chapter, regularly led student groups to learn bird identification, ${ }^{23}$ and came to be known as an 'incomparable mistress of birdlore'. ${ }^{24}$ However, there were neither affordable nor portable field guides for her birding classes; indeed, as Bailey notes in the preface of Birds through an Opera Glass (1889), she developed her first book to address her students' 'wants and the best ways to supply them'. ${ }^{25}$ In the process, she created a simplified field guide for her birding groups; although her fellow students were interested in seeing and learning about birds in their natural environment, Bailey knew that not all of her students would have the time or inclination to become ornithologists, or even to master the vocabulary of ornithology.${ }^{26}$ Compiling

\footnotetext{
20 Raymond T. Korpi, “A most engaging game”: The evolution of bird field guides and their effects on environmentalism, ornithology, and birding, 1830-1998' (PhD diss., Washington State University, 1999), 32.

21 Ibid., 14-43.

22 Florence A. Merriam, Birds of Village and Field: A Bird Book for Beginners (Boston, MA: Houghton, Mifflin and Co., 1898), iv.

23 Kofalk, No Woman Tenderfoot, 34-7.

24 Paul H. Oehser, 'In memoriam: Florence Merriam Bailey', The Auk69 (1952): 19-26, doi.org/10.2307/4081288.

25 Merriam, Birds through an Opera Glass, v.

26 Ibid., v-vi.
} 
a series of notes she had previously published in Audubon Magazine about common birds and 'how to know them', Bailey drew on her experiences in leading birding groups and produced the first 'modern' bird guide. ${ }^{27}$

From the first page, Bailey's bird books differed from other ornithology publications. Instead of scientific terms and dichotomous keys, her book was charming, unpretentious and useful. ${ }^{28}$ Simply stated, Bailey used common terms and a relatable style of writing to communicate with her audience: the public at large. Her writing style was romantic, simple and flowing, which was quite a contrast to the short and detached descriptions found in other bird books. Early bird guides, such as Grant's Our Common Birds and How to Know Them, devoted no more than one page to a particular species of bird. Grant's sentences were brief and focused on basic attributes and colours. For instance, he described cedar waxwings as indistinct birds with a crested head, 'forehead and sides of head black, indistinctly bordered with white; a small white streak under the eye', and ventured to use only one metaphor when referring to the bird's crest and back as 'cinnamon' coloured. ${ }^{29}$ In Birds through an Opera Glass, however, Bailey offered an equally detailed yet more engaging portrayal by noting the 'soft fawn tone' of the cedar waxwing's plumage, 'lit up by touches of color' such as 'a tipping of [a] bright red horny substance that look[ed] like sealing-wax on the shorter feathers of its wings' ${ }^{30}$ In contrast to Grant, she used anywhere from four to eight pages to complete the physical description of a species, and relied on the effective use of figurative language (especially in her earlier birding books where coloured plates were few and far between) to bring her birds 'to life'.

In addition, Bailey used common (and preferably colloquial) names rather than official, scientific names of birds in her early identification guides, thereby drawing upon existing public knowledge. This was most evident in her first book (Birds Through an Opera Glass), in which she outlined basic ornithology and introduced 70 common backyard birds (such as the ubiquitous American robin, blue jay and northern flicker) so that all could participate with and understand birds in their surrounding environment, regardless of experience or knowledge. For example, when describing common, cryptically coloured ground birds such as the eastern whip-poor-will and the common nighthawk, she classified them under the collective colloquial term 'goatsuckers', a name based on the mistaken belief that these birds sucked milk from goats, rather than the scientifically accurate term of 'Caprimulgiformes', an order of nocturnal, insectivorous birds identified by their small, weak legs. ${ }^{31}$ She called chipping sparrows by the well-known, friendly name

27 Ibid., v-vii.

28 Oehser, 'In memoriam: Florence Merriam Bailey', 20.

29 John B. Grant, Our Common Birds and How to Know Them (New York: Charles Scribner's Sons, 1893), 147.

30 Merriam, Birds through an Opera Glass, 112-13.

31 Ibid., 155. 
of 'chippy' and referred to bobolinks (sparrow-like birds widespread in grasslands) as 'Rice-Birds' or 'Reed-Birds. ${ }^{32}$ She also listed various colloquial names next to the common names when available, such as the Baltimore oriole, which was also commonly known as the 'Fire-Bird', 'Golden Robin' or 'Hang-Nest.'33 Latin names were conspicuously absent in her writings until the 1902 publication of her Handbook of Birds of the Western United States (detailed later in this paper). While Linnaean taxonomy is useful for organising bird families, Bailey saw it as a 'lion's roar of technical terms and descriptions to warn [the reader] of raging dullness' that could discourage the public from becoming involved in birdwatching. ${ }^{34}$ After all, the public was familiar with the American robin (called 'a great friend of America' by Bailey), but when confronted with its scientific name Turdus migratorius, very few knew to which bird this referred. ${ }^{35}$

With birds separated into 'seventeen orders, and divide[d] into numerous families and genera and species', Bailey believed the classification system to be too complex and impractical for the common bird observer. In fact, in Birds through an Opera Glass, Bailey jokingly added that 'we should have to turn pension-office clerks to get pigeon-holes enough for [birds]! ${ }^{36}$ Especially evident in her beginners' bird guides, Bailey grouped common birds into 14 such 'pigeon-holes' based on a given bird's commonness and habitat. In the preface of her second bird guide, Birds of Village and Field: A Bird Book for Beginners (1898), she stated that 'scientific classification has been disregarded, and the birds which readers are most likely to know and see are placed first'. ${ }^{37}$

Instead, to aid identification, Bailey designed simplified field keys for her early bird guides. In Birds through an Opera Glass, she included an extensive appendix to identify birds by various basic characteristics, such as range, size, plumage colour, song and behaviour. ${ }^{38}$ For size, she used America's favourite bird-the American robin—as a standard, and roughly categorised birds as larger, about the same size, or smaller than a robin. While other ornithologists, such as Grant, included average measurements of birds in their descriptions, it was easier to imagine the size of a ruby-crowned kinglet in comparison to an American robin rather than a ruler. The field key for behaviour, called 'Marked Habits' in Birds through an Opera Glass, contained the categories 'phlegmatic, meditative, fond of sitting quietly', 'restless, constantly flitting about' and 'loquacious' - all practical descriptions absent in more technical bird guides of the same period. ${ }^{39}$ With respect to song, Bailey categorised

32 Ibid., 27-60.

33 Ibid., 52.

34 Ibid., v.

35 Merriam, Birds of Village and Field, 17-18.

36 Merriam, Birds through an Opera Glass, 60-1.

37 Merriam, Birds of Village and Field, xiii.

38 Merriam, Birds through an Opera Glass, 214-9.

39 Ibid., 217. 
birds as either 'singers' or 'trillers'; 'singers' were then further split into more distinct groups, such as 'particularly plaintive', 'especially happy', 'short songs' and 'long, loud songs'.$^{40}$ In Birds of Village and Field, she developed more thorough and detailed dichotomous keys that depended mostly on plumage colour, but also incorporated various other characteristics such as overall shape, movements, flight, localities frequented, food, song, habits and nest ecology.$^{41}$ Equipped with the basic tools for bird identification, Bailey's audience was now ready for the next phase: observation and interpretation.

\section{Awareness and appreciation}

To place bird identification in a more meaningful context, Bailey included scientific explanations and ecological insights in her bird guides and encouraged the reader to interact with their environment through quiet observation of living birds in their natural habitat. As she argued in her second bird guide, Birds of Village and Field, anyone and everyone could respectfully engage with their feathered neighbours; for 'four things only are necessary ... a scrupulous conscience, unlimited patience, a notebook, and an opera-glass. ${ }^{42}$ More importantly, Bailey wanted 'birding' to transcend a leisurely hobby. In the preface of Birds through an Opera Glass, she re-emphasised the fundamental importance of quiet observation. Not only would a 'student who goes afield armed with opera-glass and camera ... add more to our knowledge than he who goes armed with a gun, but will gain for himself a fund of enthusiasm and a lasting store of pleasant memories'. ${ }^{43}$ She was strongly opposed to bird hunting, whether it be by plumers, farmers, recreational hunters or even fellow ornithologists for scientific purposes. As detailed in the respected American naturalist John Burroughs' essay collection Wake-Robin (1871), 'the pursuit, the chase, [and] the discovery' resulting in the collection of birds was a common method of study at the time. With other means available, Bailey felt that more was to be learned from a live bird than a skin and that the culminating event in ornithology was not the capture but rather 'the moment at which the human watcher [was] able to closely observe the social life of birds'. ${ }^{44}$ In her two main beginners' bird books (Birds through an Opera Glass and Birds of Village and Field), Bailey included detailed prefaces and appendices on 'best practices' and useful hints for beginner birders, such as avoiding brightly coloured clothing, walking quietly, ${ }^{45}$ and taking

\footnotetext{
40 Ibid., 216.

41 Merriam, Birds of Village and Field.

42 Ibid., xiii.

43 Merriam, Birds through an Opera Glass, v.

44 Vera Norwood, 'Constructing gender in nature: Bird society through the eyes of John Burroughs and Florence Merriam Bailey', in Human/Nature: Biology, Culture, and Environmental History, ed. John P. Herron and Andrew G. Kirk (Albuquerque, NM: University of New Mexico Press, 1999), 51-2.

45 Merriam, Birds through an Opera Glass, ix.
} 
specific notes about bird size, colour, markings, shape, flight, locality and so forth. ${ }^{46}$ Observation would then lead to the larger concepts that Bailey sought to convey to her readers: appreciation and conservation.

Bailey highlighted key relationships between birds and their environments by subtly introducing basic concepts of evolution and natural selection, adaptation, niche partitioning and ecology, even though many of these concepts were not formally known as such at the time. She added this scientific background in the form of colourful narratives. For instance, she referred to the bobolink as an example of adaptation resulting from natural selection by describing the change in the male's plumage between seasons: while the male donned a 'jet-black shirt and vest' in the spring and summer to attract a mate, he adopted the 'ochraceous tints of his wife' in the fall and winter in order to better match his surroundings and thereby avoid predation. ${ }^{47}$ Rather than elaborating on the beauty of nature, Bailey explained that 'Nature makes no meaningless display'. She also noted the unique bill of the American crossbill; although such an unwieldy crossed bill seemed like a 'poor tool' at first glance, Bailey, again, encouraged her readers to carefully observe this species as it fed on 'a cone and extract[ed] its seeds' with a 'wonderfully adapted' bill suited to its 'peculiar needs' ${ }^{48}$ In fact, Bailey brings up diversity in bird bills several times in both of her beginners' books, describing how different bill sizes and shapes are 'modified to suit the needs of the bird'; ${ }^{49}$ again, she takes complex concepts, such as ecological adaptation to diet as well as adaptive radiation, and translates them into common-sense explanations. For example, the intricate, speckled designs on eggshells came about through the survival of the fittest, she noted, since 'those whose colors best disguise them are most likely to escape the eyes of enemies' ${ }^{50}$ Her writing also hinted at the idea of niches; that is to say, each bird species occupies a certain set of environmental conditions and functions in nature, and her illustration of niche partitioning was particularly effective: 'different birds tak [ing] various levels—stories in their out-of-doors house'. One might find 'sparrows and chewinks [towhees] ... in the basement-on the ground-floor; the wrens and thrashers on the first floor in bushes and shrubs; the indigo-bird on the third floor-low trees; the vireos and tanagers and orioles on the fourth floor-high trees; while the swallows and swifts go above all-in the air'. ${ }^{11}$ Her scientific insights, in this sense, sought to reveal the intertwined connections in the natural world and awaken her readers to the often unbeknown and unseen prevalence of birds in increasingly developed landscapes.

46 Merriam, Birds of Village and Field, 380-7.

47 Merriam, Birds through an Opera Glass, 79.

48 Merriam, Birds of Village and Field, 234-5.

49 Merriam, Birds through an Opera Glass, 169.

50 Ibid., 25-6.

51 Ibid., 158. 
Beyond their ecological significance, Bailey also made the case for protecting birds by outlining their practical importance mainly through their role as insect and seed eaters, quite often as consumers of pests that plague food production systems. In fact, she devoted a 30-page pamphlet to this single topic, How Birds Affect the Farm and Garden (1896), with the long yet upfront subtitle, 'A series of facts determined by investigation of the food habits of our common birds, showing their character as insect destroyers and their value as allies of the farmer and fruit grower' ${ }^{52}$ In this publication (as well as throughout Birds of Village and Field), she meticulously detailed exactly which bothersome insects common birds species ingest and ways to attract these 'natural' helpers by creating an appealing habitat. Cedar waxwings, for example, were known as 'cherry birds' because of their potential ability to ruin cherry crops. Yet a group of 30 waxwings could destroy over 9,000 bothersome cutworm caterpillars in one month. In order to 'attract [cedar waxwings] and secure [their] help in destroying caterpillars', one could plant a variety of common shrubs and bushes such as blackberry, wild cherry, dogwood or black elder. ${ }^{53}$ Using many more examples, Bailey showed that the presence of birds could actually lead to economic benefits, even in production systems, where they were usually regarded as a nuisance.

Bailey agreed with Roosevelt and his fellow conservationists that birds needed protection from the millinery trade and thoughtless slaughter in the name of fashion, but she argued that everyone could and should play a role in this effort. In her beginners' bird books, Bailey specifically encouraged the public to take joy in observing live birds, while inserting and translating information on how to entice birds into backyards everywhere, all part of an ongoing campaign to protect bird life. ${ }^{54}$ While federal bird reservations set aside key habitats in order to protect birds, Bailey gave her audience the tools and knowledge to effectively create their own bird refuges—right in their own backyards: as Bailey wisely informed her readers, 'protection from enemies, food to live on, and suitable nesting sites are the three considerations ... [that] determine a bird's place of residence. ${ }^{55}$ Thus Bailey elevated her audience to a position in which they not only could understand and appreciate the ecosystem and economic services birds provided, but from which they could begin to act directly as protagonists in the greater conservation movement.

52 Florence A. Merriam, How Birds Affect the Farm and Garden (New York: Forest and Stream, 1896).

53 Ibid., 10-11.

54 Madelyn Holmes, American Women Conservationists: Twelve Profiles (Jefferson, NC: McFarland, 2004), 45.

55 Merriam, Birds of Village and Field, xxiv. 


\section{Passion and persuasion}

Solidifying this new-found commitment to conservation, Bailey used her writings to develop an emotional bond between her readers and the birds she sought to protect. This was by no means a new style of persuasive writing. Indeed, many of the women of the Audubon Societies had written emotionally charged articles that exploited feelings of empathy amongst sensitive readers. For instance, the Audubon Society member Annie H. Nutty's article 'Cruelty to birds' in the New York Times described how one could hear the cries of an ostrich more than a mile away as its feathers were pulled and plucked one by one for use in the fashion trade. ${ }^{56}$ Other popular articles, such as 'Spare the birds', depicted heart-wrenching stories of 'motherless young [birds]' that were left to starve after their parents were shot by 'cruel' plumer gangs. ${ }^{57}$ And perhaps the most moving and popular piece, Mary Thatcher Higginson's 'The slaughter of the innocents', illustrated the plight of birds by using human feelings of pain, loss and despair: 'the outspread wings have lost their magic power, and the little feet, instead of clasping some swaying bough, have been hopelessly entangled in the meshes of velvet and lace'. ${ }^{58}$ Interestingly enough, Bailey, who was part of the wealthy upper class herself, was also a member of the Audubon Society and consequently utilised the same method of shaming her readers into rejecting the frivolous use of birds for fashion, especially in her earliest articles, such as 'Bird murder'. ${ }^{59}$ However, Bailey realised the shortfalls of this approach as it tended to leave her readers feeling castigated. Instead she adopted a more positive, relatable writing style that emphasised the pleasure obtained from interacting with birds, and thus led by example: as detailed in Harriet Kofalk's thorough biography, Bailey 'spoke out for life, rather than against injustice'. ${ }^{60}$

Bailey gave a human face and feeling to birds, thereby creating less divisive lines between humans and birds. ${ }^{61}$ Rather than provide brief, dispassionate descriptions of birds as with many other ornithology publications of the time, Bailey interpreted bird activities and interactions as vivid stories, personifying the life of birds to the life of people. She focused on social and cooperative behaviours, and highlighted specific activities that correlated most closely to the daily activities of her readers, such as raising a family. In Birds through an Opera Glass, she transformed the songs of birds into sentences or conversations. For the western wood pewee, she suggested that its song resembled 'all the happiness of domestic love and peace'. ${ }^{62}$ The American crow, whose 'vocabulary' made him 'a very Shakespeare among birds',

56 Annie H. Nutty, 'Cruelty to birds', New York Times, 20 July 1897.

57 Louisa J. Bruen, 'Spare the birds', New York Times, 1 March 1897.

58 Mary Thatcher Higginson, 'The slaughter of the innocents', Harper's Bazaar, 22 May 1875, 338.

59 Florence A. Merriam, 'Bird murder', New York Times, 9 May 1896.

60 Kofalk, No Woman Tenderfoot, xviii-4.

61 Norwood, 'Constructing gender in nature', 55-8.

62 Merriam, Birds through an Opera Glass, 86-7. 
often seemed to have complicated conversations between flock members, similar to human dialogues at the dinner table or small quarrels between parents and children. As Bailey noted in a 'conversation' between a father and son crow, 'to everything he said, whether in a complaining or teasing tone, the same gruff paternal caw came back from the pasture. "Come along!" it seemed to say. To this the refractory son would respond, "I won't". ${ }^{33}$ Beyond 'speaking', birds seemed to share other emotions with human beings. When describing the cedar waxwing, Bailey remarked upon 'the gentle affectionate nature' of these birds and how they had even 'adopted the human symbol of tenderness ... kissing each other' ${ }^{64}$ At times, Bailey blurred the line between birds and humans to such an extent that her account of an American robin family could have easily passed as a description of the ideal American family. In her eyes, American robins exhibited such 'human tenderness ... in their family relations, not only in caring for their little ones, but in the small offices of daily happy companionship ... as they work[ed] together for their brood'. ${ }^{65}$

Interestingly, and perhaps a personal insight into the author's opinions on gender politics, Bailey often commented on interactions between 'husband' and 'wife' birds and inequalities between the sexes. For example, in Bailey's description of the blackthroated blue warbler in Birds through an Opera Glass, she breaks from her normal prose into a short, frustrated aside about the injustice of bird names, in that 'little feathered birds have to bear their husband's names, however inappropriate' ${ }^{66}$ In the case of the black-throated blue warbler (and many bird species, as they are often sexually dimorphic, with males bearing bright, colourful plumage in comparison to females), Bailey noted the masculine origins of bird names: 'Here, an innocent creature with an olive-green back and yellowish breast has to go about all her days known as the black-throated blue warbler, just because that happens to describe the dress of her spouse!' ${ }^{67}$ At the end of this passage, she exclaims, 'Talk about woman's wrongs!' Throughout Birds through an Opera Glass, Bailey points out the differences in plumage of male and female birds; although male birds typically look more 'beautiful' with their bright colours and are often easier to identify due to their characteristic plumage, Bailey implores her readers to also appreciate the female birds. For example, male red-winged blackbirds have black plumage accentuated by strikingly red epaulettes (a patch of feathers on the bird's 'shoulders'), whereas females from the same species have a streaky brown plumage with light, salmoncoloured epaulettes; here, Bailey argues that despite the somewhat drab plumage of the female, 'the effect is pleasing, and it is only a matter of taste if we do not admire her as much as her spouse'. ${ }^{68}$ In a way, Bailey's writing could be interpreted as her

63 Ibid., 10-11.

64 Ibid., 113-14.

65 Merriam, Birds of Village and Field, 17-18.

66 Merriam, Birds through an Opera Glass, 186-7.

67 Ibid., 187.

68 Ibid., 91. 
opinions on gender politics and gender equality more broadly, or perhaps specifically the under-representation and/or challenges of being a woman ornithologist. Whatever the motivation behind these passages, it is clear that Bailey was very aware of (and frustrated with) gender inequality; moreover, in personifying birds, she also personified gender politics-perhaps another method by which to bring a 'face' to the birds that she sought to describe and share with her readers.

Gender-related anecdotes, such as those described previously, are quite common throughout Birds through an Opera Glass, which was originally prepared by Bailey for beginner (women) birders at Smith College. In writing a book (originally) geared towards women birders, it may not seem all that surprising in the examples of gender inequality as well as a push for gender equality (i.e. by appreciating female birds, regardless of the appearance of their plumage). However, in her second beginners' book of Birds of Village and Field, Bailey interweaves gender politics and birds far less fervently or frequently. (Also, as an aside, Bailey was married in 1899, a year after Birds of Village and Field was published.) In Birds of Village and Field, Bailey often shares stories of cooperation between bird parents and focuses on intraspecies interactions. Here, Bailey highlights male and female birds (mates) working together, building nests together, and feeding their chicks together; she seems to observe no gendered division of labour. For example, when providing an account of quail, Bailey argues that these species have a 'particularly interesting' domestic life, with the male 'helping to build the nest, feeding his mate on the eggs, and, in the case of her death, brooding in her place' ${ }^{69}$ In these passages about 'family government and parental care', Bailey impresses upon the reader notions of cooperation and familial affection, in some ways quite a departure from her tone in Birds through an Opera Glass, which was sometimes quite critical. Just as Bailey shifted from shaming readers in her early articles to educating her readers about bird life, it may also be that she perceived some drawbacks of incorporating gender politics into her prose and observations. Instead of underscoring issues in gender inequality and personifying gender politics in birds, Bailey may have thought her bird identification books should share insights into bird life, not necessarily human politics, perhaps making her bird books more accessible to an even wider audience. And, by extension, by drawing on the cooperative interactions among birds, Bailey may very well have also highlighted positive examples of gender equality for her readers to observe among avifauna.

Often writing from a first-person perspective, Bailey shared her awe of the natural environment through narratives of her personal experiences with birds. When she discovered a ruby-throated hummingbird sitting upon a bare branch, she could 'scarcely appreciate what a wee mite of a bird it [was] ... for it dart[ed] off and

69 Merriam, Birds of Village and Field, 39. 
[was] gone like the flash of a diamond'. ${ }^{70}$ Her writings captured the essence of coming across one of her feathered friends, almost like encountering an old acquaintance. Pygmy nuthatches were her favourite and as the 'fluffy, bob-tailed little pygmies [came] trooping in and alight upside down against the tips of the pine branches, talking in soft little liquid notes', Bailey could hardly contain herself from exclaiming 'Oh, you winsome little mites, how jolly it is to see you again!?71 $\mathrm{Her}$ enthusiasm was infectious and she sought to ignite a similar fervour in her readers. Moreover, with a growing public interest in nature and transcendentalist writings, Bailey included poems and quotations from celebrated early conservationists and poets such as Henry Wadsworth Longfellow, Henry David Thoreau, James Russell Lowell and Percy Bysshe Shelley in her publications. Perhaps used to 'popularise' her writings, passages from these well-known figures brought in different ideas and developing attitudes towards the natural environment, complementing her own observations and sentiments. Bailey may have chosen to emphasise ideas related to transcendentalism and environmentalism instead of the utilitarian philosophy (i.e. preservation of natural resources rather than nature) embodied by government agencies (e.g. the US Forest Service) in order to establish a sense of admiration for avifauna among her readers, and in turn, the basis for avian conservation. ${ }^{72}$ Writers such as Longfellow, Thoreau and others deeply appreciated and respected the beauty of the natural environment and also wrote about it with elegance and reverence. Not only were these writers able to describe the wonders of nature, but they were also effective in their arguments for the necessity of conserving it-thus, Bailey may have inserted passages from these writers to amplify her message of avian conservation. For example, Lowell's poems appeared throughout Birds through an Opera Glass and Bailey even cited a description from Thoreau for the song of the bobolink: 'It is as if he touched his harp within a vase of liquid melody, and when he lifted it out the notes fell like bubbles from the trembling strings ... they are the most liquidly sweet and melodious sounds I have ever heard' ${ }^{73}$ By using a positive approach in her personal observations and anecdotes, Bailey developed an emotional appeal that made the case for conservation even more powerful. This, in turn, established a moral shift away from the thoughtless exploitation of birds for vanity.

\footnotetext{
70 Merriam, Birds through an Opera Glass, 36.

71 Florence M. Bailey, Handbook of Birds of the Western United States: Including the Great Plains, Great Basin, Pacific Slope, and Lower Rio Grande Valley (Boston, MA: Houghton, Mifflin and Co., 1902), 454, doi.org/10.5962/bhl. title.7872.

72 Lawrence Buell, The Environmental Imagination: Thoreau, Nature Writing, and the Formation of American Culture (Cambridge, MA: Harvard University Press, 1995), 137-8.

73 Merriam, Birds through an Opera Glass, 32.
} 


\section{In conclusion and beyond}

Florence Augusta Merriam Bailey became a strong advocate for avian conservation in response to the 'feather trade' of the late nineteenth and early twentieth centuries that decimated bird populations only to cater to the fashion world. Riding on the rising tide of the conservation movement already set in motion by popular figures such as Henry David Thoreau and John Muir, conservationists and other special interest groups rallied around this cause. Arguments against the senseless slaughter of birds ranged from passionate admonishments based upon morality (the Audubon Society) to scientifically supported (and utilitarian-fuelled) proposals for the preservation of natural resources, including birds, for the benefit of society (Roosevelt and fellow conservationists).

Bailey used both scientific reasoning and emotional appeal to further the cause of bird conservation. She was convinced that if a larger segment of society observed birds and studied their habits, they would join the ranks of ornithologists, conservationists and bird-lovers alike to work for their protection. She felt that conservation should not be a luxury activity indulged in by the few; rather, everyone could play a role in this growing movement, starting right outside one's front door. Her popular writings and bird guides, although very much a product of the time as is evident in the overly romantic descriptions, made conservation accessible to a far broader audience by using simplified terminology and drawing distinct parallels between the lives of people and the lives of birds. Bailey saw and contended that humans were in fact part of nature-just as much as birds. For 'wherever there are people there are birds, so it makes comparatively little difference where you live, if you are only in earnest about getting acquainted with your feathered neighbors' ${ }^{74}$ Bailey made the case for the utilitarian preservation of birds on the basis of ecosystem services (such as consuming pest insects, and assisting with pollination and seed dispersal), arguing that the very foundation of agriculture hinged on protecting birds ${ }^{75}$ as such, our survival was intrinsically tied to the natural environment. But Bailey wanted to move beyond this limited perspective, and invited the public to observe, understand and appreciate birds in their own right. Birds had an intrinsic value, but also provided something that could not be measured or quantified otherwise; by providing guides that taught the public how to take time to create a connection with the natural world and birds, Bailey believed that birds could provide a 'fund of enthusiasm and a lasting store of pleasant memories' ${ }^{76}$ In a sense, Bailey democratised ornithology with the objective of actively engaging ordinary people in the process of conservation.

74 Ibid., iii

75 Merriam, How Birds Affect the Farm and Garden, 3-7.

76 Merriam, Birds through an Opera Glass, v. 
Herein lies the strength and the current relevance of her message. Even today, the environmental education of the public and their active participation in the science of conservation as citizen/community scientists has the highest priority.

Beyond her Audubon Magazine articles and two beginners' bird guides (Birds Through an Opera Glass and Birds of Village and Field), Bailey published extensively and diversely. With almost 100 journal articles and 10 books to her credit, Bailey covered genres ranging from personal travel narratives (such as A-Birding on a Bronco, 1896) to scientific ornithology manuals (such as the Handbook of Birds of the Western United States, 1902, and Birds of New Mexico, 1928). During her lifetime, Bailey was widely recognised both within as well as outside the scientific community for her indispensable contributions to the field of ornithology. Described as 'one of the most literary ornithologists of her time', Bailey combined her passion for birds and power of keen observation 'with a fine talent for writing and a high reverence for science. ${ }^{77}$

Despite her decision to disregard taxonomy in her beginners' bird guides, Bailey was neither ignorant of nor resistant to using scientific terminology. She was a true ornithologist but also an excellent science communicator, balancing information with application and stories in her beginners' bird books. Even in her more scientific manuals, Bailey did not 'ignore the individuality' of birds $;{ }^{78}$ instead, she used her personal detailed observations to supplement technical descriptions. Moreover, it is worth noting that Bailey did employ the official 'classification, nomenclature, and numeration ... of the A[merican] O[rnithologists'] U[nion] Check-List of North American Birds' in the Handbook of Birds of the Western United States, a more technical publication aimed at professional birders and serious laypeople. ${ }^{79}$ This book was considered by many as her most important addition to the bibliography on birds and was treated as the touchstone textbook for western bird identification for nearly half a century. ${ }^{80}$ Published in 1902, the Handbook was subsequently reissued in 17 editions and four revisions. ${ }^{81}$ Her final bird identification manual, Birds of New Mexico, was the culmination of a lifetime's work of study and writing about birds, long considered to be the standard in the field. In 1929, the American Ornithologists' Union (AOU) - the nation's oldest organisation devoted to the scientific study of birds - elected Bailey as its first woman fellow. Two years later, the AOU honoured Bailey with the Brewster Medal, an award given every two years to the author of the most important book on birds of the western hemisphere. ${ }^{82} \mathrm{Her}$ last major written work, entitled Among the Birds in the Grand Canyon Country, was

77 Oehser, 'In memoriam: Florence Merriam Bailey', 21.

78 Merriam, Birds through an Opera Glass, 188.

79 Bailey, Handbook of Birds of the Western United States, xxv.

80 Oehser, 'In memoriam: Florence Merriam Bailey', 22.

81 Holmes, American Women Conservationists: Twelve Profiles, 48-53.

82 Marcia Bonta, Women in the Field: America's Pioneering Women Naturalists (College Station: Texas A\&M University Press, 1991). 
published by the National Park Service in 1939. Through all her articles, books and guides, Bailey embodied the same approach — a quiet, dedicated study of nature. She encouraged calm contemplation and appreciation among her readers, urging them to 'cultivate a philosophic spirit, be content to sit and listen ... let the fascinating, mysterious, bewildering voices encompass you and—hold your peace'. ${ }^{83}$

Bailey was instrumental in creating the public foundation of the early conservation movement, although at the time she did not have such grand ambitions. Her intention was simple and straightforward: to share her passion for birds with the public at large, to spread the joy and appreciation of living birds in their natural habitat, and to shift the emphasis from fatal fashions to caring actions.

83 Florence Merriam Bailey, 'Characteristic birds of the Dakota Prairies. III. Among the sloughs and marshes'. The Condor 18 (1916): 14-21. 
This text is taken from International Review of Environmental History, Volume 7 , Issue 2, 2021, edited by James Beattie, published 2021 by ANU Press,

The Australian National University, Canberra, Australia.

doi.org/10.22459/IREH.07.02.2021.02 